\title{
PROCEDURES FOR DETERMINING DRAINAGE AREAS USING A DIGITIZER, DIGITAL COMPUTER, AND TOPOGRAPHIC MAPS
}

By Robert L. Gold and Dan Winkless

U.S. GEOLOGICAL SURVEY

Water-Resources Investigations Report 86-4083

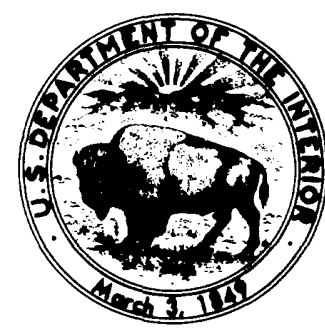

Albuquerque, New Mexico 


\author{
DEPARTMENT OF THE INTERIOR \\ DONALD PAUL HODEL, Secretary \\ U.S. GEOLOGICAL SURVEY \\ Dallas L. Peck, Director
}

For additional information

write to:

District Chief

U.S. Geological Survey Water Resources Division

Pinetree Office Park

4501 Indian School Rd. NE, Suite 200

Albuquerque, New Mexico 87110
Copies of this report can be purchased from:

U.S. Geological Survey

Books and Open-File Reports Section

Federal Center

Box 25425

Denver, Colorado 80225 


\section{CONTENTS}

Page

Abstract $\ldots \ldots \ldots \ldots \ldots \ldots \ldots \ldots \ldots \ldots \ldots \ldots \ldots \ldots \ldots \ldots \ldots \ldots \ldots \ldots \ldots \ldots \ldots$

Int roduction $\ldots \ldots \ldots \ldots \ldots \ldots \ldots \ldots \ldots \ldots \ldots \ldots \ldots \ldots \ldots \ldots \ldots \ldots \ldots$

Procedures for the determination of drainage area $\ldots \ldots \ldots \ldots \ldots \ldots \ldots . . . .2$

Description of computer program used to compute drainage area $\ldots \ldots \ldots 5$

Computer/digitizer program procedure $\ldots \ldots \ldots \ldots \ldots \ldots \ldots \ldots \ldots \ldots \ldots$

Computation, tabulation, and computer-printout record $\ldots \ldots \ldots \ldots \ldots$

Drainage-area computation sheets ...................... 13

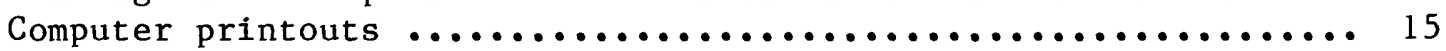

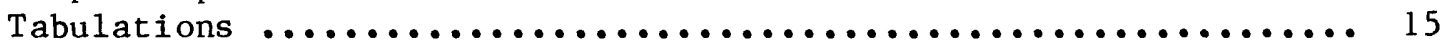

References $\ldots \ldots \ldots \ldots \ldots \ldots \ldots \ldots \ldots \ldots \ldots \ldots \ldots \ldots \ldots \ldots \ldots \ldots \ldots \ldots \ldots \ldots$

Supplemental information $\ldots \ldots \ldots \ldots \ldots \ldots \ldots \ldots \ldots \ldots \ldots \ldots \ldots \ldots \ldots$

\section{FIGURES}

Figure 1. Map showing delineation of quadrilaterals and a drainage

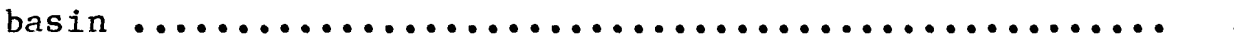

2. Diagram showing primary, secondary, and tertiary labels in a quadrilateral for a drainage basin ....... 4

3. Diagram showing digitizer cursor $\ldots \ldots \ldots \ldots \ldots \ldots \ldots \ldots \ldots \ldots$

4. Diagram showing digitizer menus $\ldots \ldots \ldots \ldots \ldots \ldots \ldots \ldots \ldots$

5. Example of first drainage divide drawn through a quadrilateral ..............................

6. Example of a drainage basin wholly contained in one

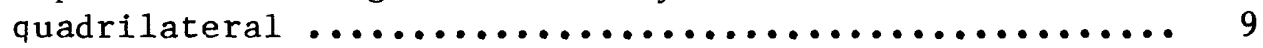

7. Drawing of basin divide showing digitized data points .... 10

8. Example of a listing of computer file containing drainage-area program results $\ldots \ldots \ldots \ldots \ldots \ldots \ldots \ldots \ldots \ldots$

9. Example of a computation sheet $\ldots \ldots \ldots \ldots \ldots \ldots \ldots \ldots \ldots \ldots$

10. Example of a tabulation sheet $\ldots \ldots \ldots \ldots \ldots \ldots \ldots \ldots \ldots \ldots \ldots$ 


\section{CONVERSION FACTORS}

For use of readers who prefer to use metric units, conversion factors for terms used in this report are listed below:

Multiply inch-pound unit

mile

square mile

square inch
By

$$
\begin{array}{r}
1.609 \\
2.590 \\
645.2
\end{array}
$$

To obtain metric unit

kilometer

square kilometer

square millimeter

Sea level: In this report "sea level" refers to the National Geodetic Vertical Datum of 1929 (NGVD of 1929)--a geodetic datum derived from a general adjustment of the first-order level nets of both the United States and Canada, formerly called "Mean Sea Level." 


\title{
PROCEDURES FOR DETERMINING DRAINAGE AREAS USING A DIGITIZER,
}

\author{
DIGITAL COMPUTER, AND TOPOGRAPHIC MAPS
}

\author{
By Robert L. Gold and Dan Winkless
}

\begin{abstract}
This report documents procedures for determining drainage areas using a digitizer, digital computer, and topographic maps. The procedures described are applicable to all users who have a Prime minicomputer. A Fortran 77 computer program, written for use on the Prime minicomputer, is used with a digitizer to determine drainage-area values.

Procedures for the delineation of drainage-basin divides and the types of maps to be used also are described. The forms to be used in documenting the drainage-area determinations and the filing system for storage of these forms are outlined.
\end{abstract}

\section{INTRODUCTION}

Drainage area is an important basin characteristic in studies of surface water. It has been used as a means to transfer data regionally and as a factor in statistical analyses. Drainage areas also can be used in estimating streamflows required for the planning and design of projects such as watersupply systems, wastewater-treatment facilities, flood-control structures, and bridges. Precise determination of drainage areas is, therefore, of prime concern to those who work in the field of water resources.

Standard procedures and accuracy limits for the determination of drainage areas have been outlined by the Federal Inter-Agency River Basin Committee, Subcommittee on Hydrology (1951). The procedures described in that report are based on the use of the planimeter in the computation of drainage area. The contemporary digitizer and computer are now used by many U.S. Geological Survey offices to compute drainage areas. This report documents procedures for determining drainage areas using the digitizer and the digital computer.

The procedures documented in this report are based on work done by J.D. Hendrix (U.S. Geological Survey, written commun., 1976). These procedures have received approval for use throughout the U.S. Geological Survey (H.C. Riggs, U.S. Geological Survey, written commun., 1977). Therefore, the methods described herein are applicable nationwide. This report may be used as an instructional guide for determining drainage areas using the Prime ${ }^{1}$ minicomputer and the Talos digitizer.

${ }^{1}$ Use of the trade names and firm names in this report is for identification purposes only and does not constitute endorsement by the U.S. Geological Survey. 


\section{PROCEDURES FOR THE DETERMINATION OF DRAINAGE AREA}

In determining drainage area, the Federal Inter-Agency River Basin Committee, Subcommittee on Hydrology (1951) suggests that, "Drainage area boundaries should be established with utmost care, utilizing skilled personnel experienced in hydrology and cartography. Much personal judgement must be used, even at best, but advantage should be taken of all available information to minimize guesswork and need for personal judgement. The fundamental requirement for accurate results is an accurate boundary traced on a map of precise scale."

The person who is to delineate the drainage area of a basin first needs to select the proper topographic map or maps. The delineation of drainage areas needs to be made on the most complete and up-to-date maps available for the area. The maps generally used are $7 \frac{1}{2}$-minute $(1: 24,000)$ U.S. Geological Survey topographic quadrangle maps. If an area is not covered by a $7 \frac{1}{2}$-minute map, a 15-minute $(1: 62,500)$ topographic quadrangle map is used. The drainage divide then will be traced as shown in figure l, starting at a point on the stream and using the topographic contours as a guide. Extra care needs to be taken in the delineation of drainage divides in areas with low relief or in areas with poorly defined drainage networks. If possible, field reconnaissance of these areas needs to be made. This is especially important for delineations in urban areas. Noncontributing areas (areas with no discernible surface outlet) within a drainage basin are delineated separately.

Both the 7 $\frac{1}{2}$-minute and 15-minute quandrangle maps are divided into nine quadrilaterals (fig. 1). For the $7 \frac{1}{2}$-minute quadrangle, the quadrilateral will cover $2 \frac{1}{2}$ minutes, and for the 15-minute quadrangle, the quadrilateral will cover 5 minutes. Within these quadrilaterals, the drainage basins are labeled. The primary divisions are labeled by location letter and number, such as N2 (fig. 2). Each secondary division is noted first by a letter and then a number, and so on; for example, N2a (fig. 2). This process is followed in order to identify subdivisions of an original basin. For example, in figure 2, part B, the basin for Beal Creek labeled as 2 previously had been digitized. In order to digitize only Dukes Creek basin, Beal Creek was subdivided as shown in part $C$. The labeled areas were used to identify the new digitized results.

Once the stream's drainage boundary has been properly delineated, labeled, and checked, the basin is then ready to be digitized and the drainage area computed. The next section is a description of the computer program DAREA and the section after that is a step-by-step description of the use of the drainage-area computer program. DAREA was written by Kim Dalton and Dan Winkless of the U.S. Geological Survey. A sample computer/digitizer session is listed in "Supplemental information" at the back of this report.

A11 maps used in the delineation of drainage areas need to be filed in a master map file so that they are not used for other purposes. This filing ensures that future delineations of drainage areas will be consistent with past delineations. Delineations drawn on nonmaster-file maps need to be transferred to a master-file map in order to retain a permanent record of that delineation. 


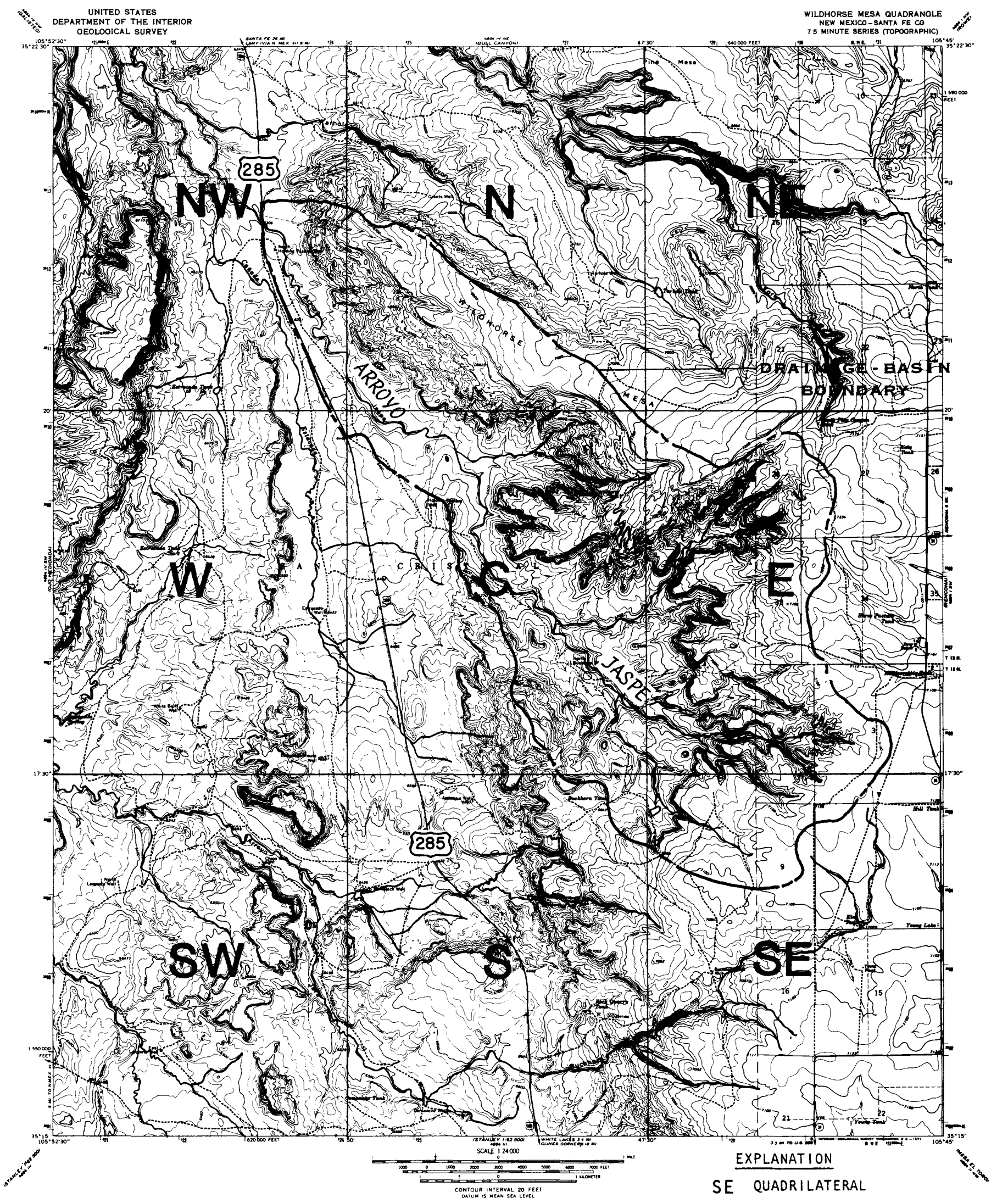

Figure 1.--Delineation of quadrilaterals and a drainage basin. 


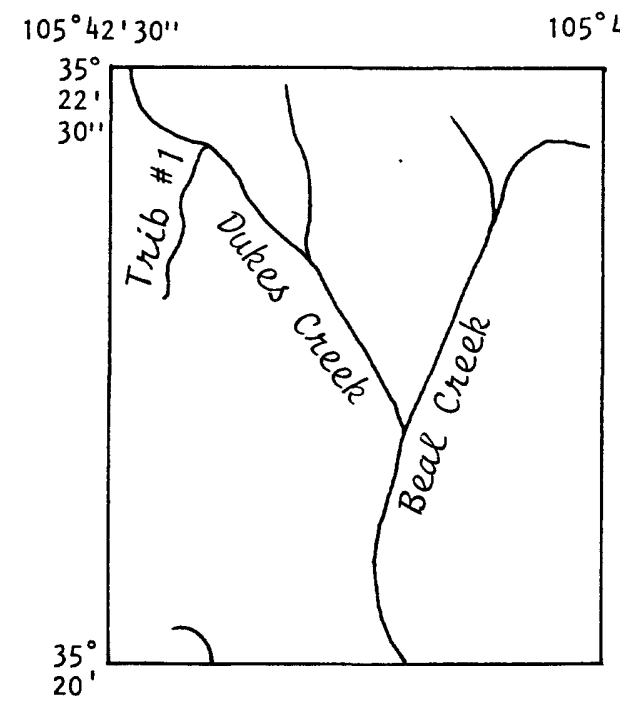

A. The north quadrilateral before any divisions are made- $-\mathrm{N}$.

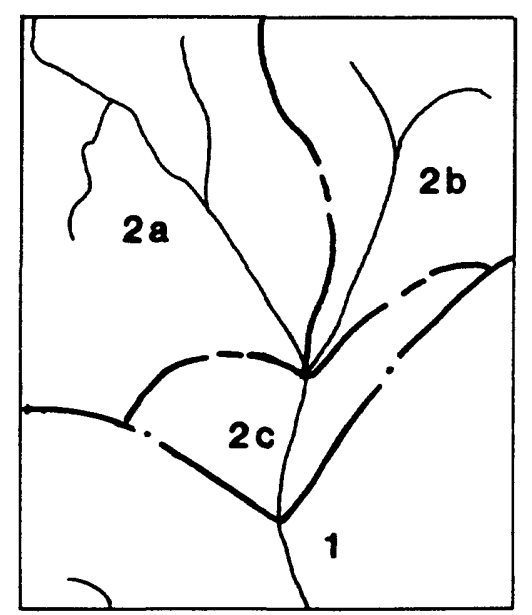

C. Secondary divisions of N2, identified by the addition of a letter-for example, N2a.

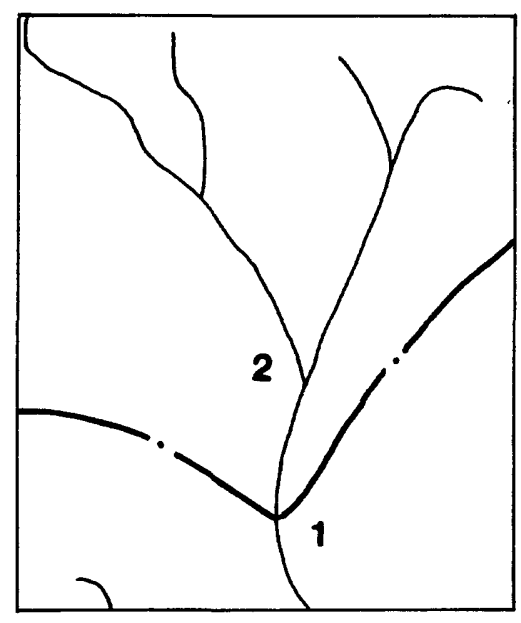

B. Primary divisions of $\mathrm{N}$ identified by whole numbers--for example, N2.

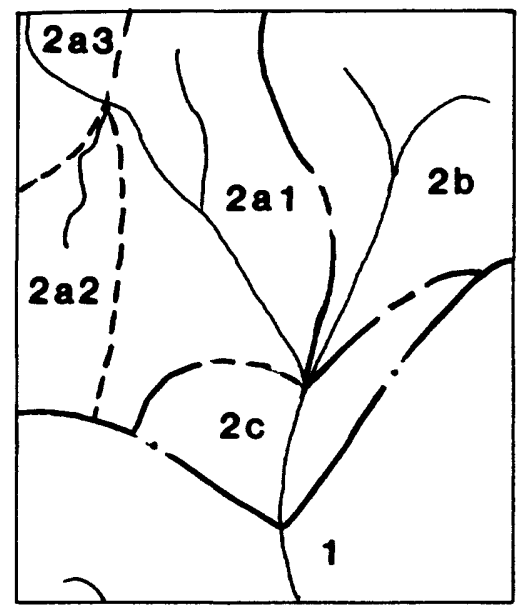

D. Tertiary divisions of $\mathrm{N} 2 \mathrm{a}$, identified by the addition of a number--for example, N2a1.

If another division is necessary, the number N2al needs to be changed to the next available small whole number--for example, N3. A change such as this needs to be noted on the computation sheet.

Figure 2.--Primary, secondary, and tertiary labels in a quadrilateral for a drainage basin. 


\section{DESCRIPTION OF COMPUTER PROGRAM USED TO COMPUTE DRAINAGE AREA}

DAREA is written in Prime Fortran 77 (Marra, 1982) to interact with the computer while using the digitizer. The program, whose source listing is in the section of this report titled "Supplemental information," produces a disk file that can be viewed at a terminal or transferred to a printer.

\section{COMPUTER/DIGITIZER PROGRAM PROCEDURE}

For illustration purposes, the following procedure refers to the fictious stream net shown in figure 2. These streams are assumed to be within the Wildhorse Mesa quadrangle shown in figure 1 .

After a drainage basin has been delineated, the drainage-area map is taped to the digitizer table. Turn on the printer/terminal. Push the RESET ${ }^{2}$ button on the digitizer controller (located at the base of the digitizer pedestal). The printer/terminal should then respond. With the digitizer cursor (fig. 3), select "ERASE LARGE MENU" and "LOCATE LARGE MENU" (fig. 4), taped to the digitizer table, by aligning the crosshairs of the cursor over the appropriate box and depressing one of the cursor keys 1-9. For simplicity, it is best to use one key number throughout the procedure. For the purpose of these instructions, key 1 will be used.

Next, select the lower left corner point of the large menu (fig. 4), also taped to the digitizer table. The large menu may now be used to select symbols and letters or to give commands to the digitizer.

Use the cursor to select symbols from the large menu in the following sequence:

$0 \mathrm{~N}$ L CR. This will bring the digitizer on line and should result in an "OK" response from the printer/terminal. An "NK" response means an unacceptable response; thus, the sequence of symbols and letters needs to be reentered. The operator then needs to 1 og in to the Prime computer and attach to the directory where the files that will be generated by DAREA are to be stored.

After the operator is attached to the proper directory, key in DAREA and RETURN on the printer/terminal keyboard. These keyed words activate the computer program, and the printer/terminal will print:

DAREA -- written by Kim Dalton and Dan Winkless, May 1983

What file do you want the information placed in ?

The input response should be the name of the file followed by a return; for example, RIVER and RETURN.

${ }^{2} \mathrm{~A}$ box encloses data to be entered into the computer from a keyboard. 


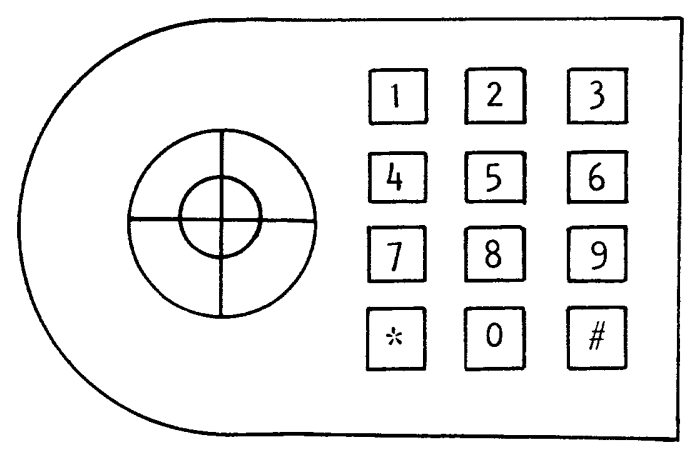

Figure 3.--Digitizer cursor.

\begin{tabular}{|c|c|c|c|c|c|c|c|c|}
\hline+ & - & $*$ & I & $\%$ & $\varepsilon$ & , & ( & ) \\
\hline , & - & : & ; & $=$ & $<$ & $>$ & ? & @ \\
\hline$\Lambda$ & $C R$ & LF & BS & SPACE & $!$ & , & \# & $\$$ \\
\hline 1 & 2 & 3 & 4 & 5 & 6 & 7 & 8 & 9 \\
\hline$\emptyset$ & A & B & C & D & $E$ & $\mathrm{~F}$ & G & $H$ \\
\hline 1 & $\mathrm{~J}$ & K & $L$ & $M$ & $N$ & 0 & $P$ & $Q$ \\
\hline$R$ & $S$. & $T$ & U & V & W & $x$ & $Y$ & $z$ \\
\hline ROTA & $\begin{array}{l}\text { SCALE } \\
\text { TRANSL }\end{array}$ & $\underset{\text { SCALE }}{X Y}$ & $\begin{array}{c}Y \\
\text { SCALE }\end{array}$ & TRANSL & $\begin{array}{c}\text { CLEAR } \\
\text { ALL }\end{array}$ & $\begin{array}{l}\text { DISP } \\
\text { FACTORS }\end{array}$ & $\begin{array}{l}\text { LENGTH } \\
\text { FACTOR }\end{array}$ & $\begin{array}{l}\text { VOLUME } \\
\text { FACTOR }\end{array}$ \\
\hline POINT & RUN & TRACK & REMOTE & INC & $\begin{array}{l}\text { ENTER } \\
\text { INCR } \\
\text { FACTOR }\end{array}$ & ANSWER & $\begin{array}{c}\text { LINE } \\
\text { LENGTH }\end{array}$ & AREA \\
\hline
\end{tabular}

LARGE MENU

\begin{tabular}{|c|c|}
\hline LOCATE & ERASE \\
\hline LARGE & LARGE \\
\hline MENU & MENU \\
\hline
\end{tabular}

Figure 4.--Digitizer menus from Talos Systems, Inc., 1979; reprinted with permission. 
The next question should read:

What is the quadrangle I.D. ?

The response should be the name of the $7 \frac{1}{2}$ - or 15-minute quadrangle on which the drainage basin is delineated. For example, key in Wildhorse Mesa 7 $\frac{1}{2}$ and RETURN.

The program then asks:

What is the published quadrangle size (sq. mi.) ?

This area can be found in table 8 of the report published by the Federal Inter-Agency River Basin Committee, Subcommittee on Hydrology (1951). To use the table, first determine the latitude of the midpoint of the quadrangle. For example, in figure 1 the midpoint latitude would be $35^{\circ} 18^{\prime}$ ' 45". From table 8, a quadrangle at this latitude has an area of 60.12 square miles. Therefore, key in 60.12 and RETURN . Areas for other quadrangles of different size, such as 15, 5, and $2 \frac{1}{2}$ minutes, are tabulated in other tables contained in the Committee's report.

The program then prompts:

\section{Digitize corners of quadrangle}

Using the digitizer cursor, the operator first selects "AREA" from the large menu (fig. 4). If the operator fails to select "AREA" and attempts to digitize the quadrangle, a value will be printed immediately on the printer/terminal when the first point is digitized. If this occurs, select "AREA" and proceed with the digitizing. The erroneous value may be deleted later in the procedure. After selecting "AREA", digitize the corners of the quadrangle with the cursor in a clockwise direction by keying 1 from the cursor at each corner. No value will be printed until the last corner is digitized. The first digitized corner also will be the last one digitized. However, key 0 for the last entry. The printer/terminal will then print out the digitized quadrangle area in square inches.

The program then asks:

What is the basin I.D. ?

Key in the letter/number designation for the basin to be subdivided on the printer/terminal. For example, for the basin illustrated in figure 2, key in $\mathrm{N} 2$ and RETURN. 
The program next asks:

What is the basin area?

Enter the basin area (in square miles) and RETURN, if known. This normally will be the previously computed area for the basin to be subdivided. If the basin area is not known, key RETURN and the program will go on to the next step.

The program next asks:

What is the sub-basin I.D. ?

The information needed is the letter/number combination identifying the subbasin to be digitized. For example, from figure 2, key in $\mathrm{N} 2 \mathrm{a}$ and RETURN .

For the special case where the drainage-basin divide is the first one through a quadrilateral ( $f i g .5$ ), the quadrilateral designation ( $N, N W, N E$, and so on) is entered as the basin I.D. The published area for the quadrilateral is entered as the basin drainage area. The two subbasins are labeled according to the previous instructions ( 1 and $\mathrm{N} 2$ in fig. 5).

Another special case is illustrated in figure 6. The drainage area is wholly contained within the quadrilateral. The published area for the quadrilateral is entered as the basin drainage area. Imaginary basin divides are drawn to the quadrilateral boundaries (dividing subbasin 1 into $\mathrm{Nla}$ and $\mathrm{Nlb}$ in fig. 6).

After the subbasin has been labeled, the program then prints:

\section{Digitize area}

Each subbasin is digitized according to the following instructions. Select "AREA" on the large menu. Choose an initial point on the subbasin, center it under the cursor crosshairs, and key in 1 from the cursor. Continue clockwise around the subbasin keying in 1 for points along the divide (fig. 7). Calculations are made in straight-line segments, so the points need to be sufficiently close together to describe the curve. Key in 0 from the cursor for the last point digitized. This point should be the same as the first point digitized. The area, in square inches, for the run will be printed, and the program will allow the subbasin to be redigitized. At least three runs should be made for each subbasin. When the areas of af least three runs agree within 0.5 percent of the mean of the runs, key in 0 from the cursor. The program then lists the sequence number and area, in square inches and in square miles, for each run. 


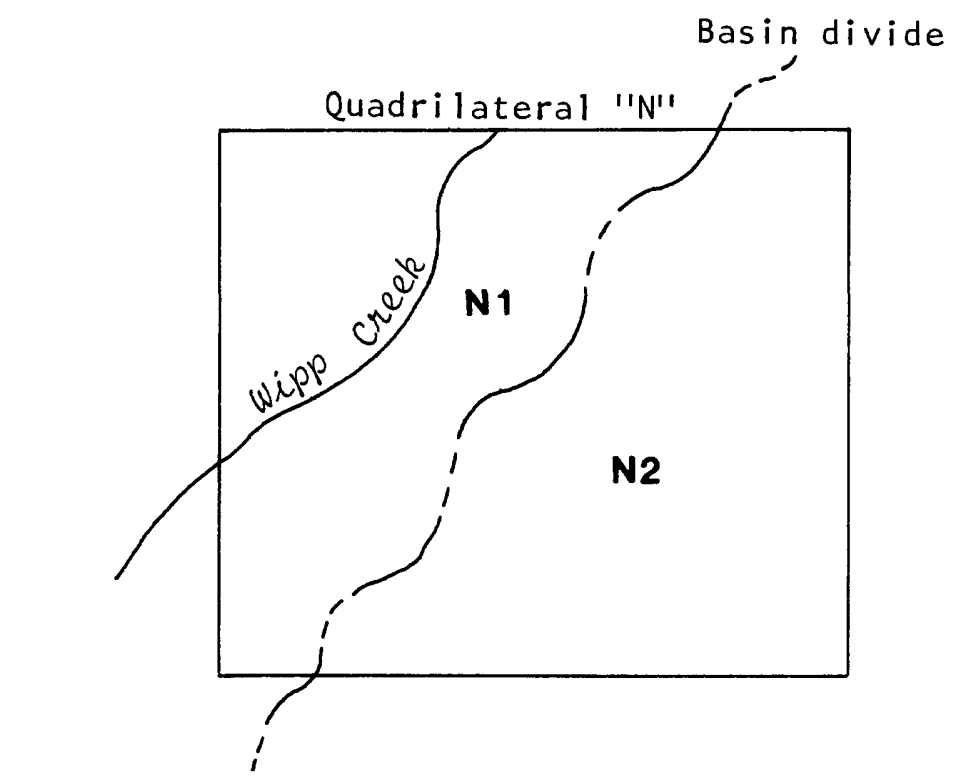

Figure 5.--Example of first drainage divide drawn through a quadrilateral.

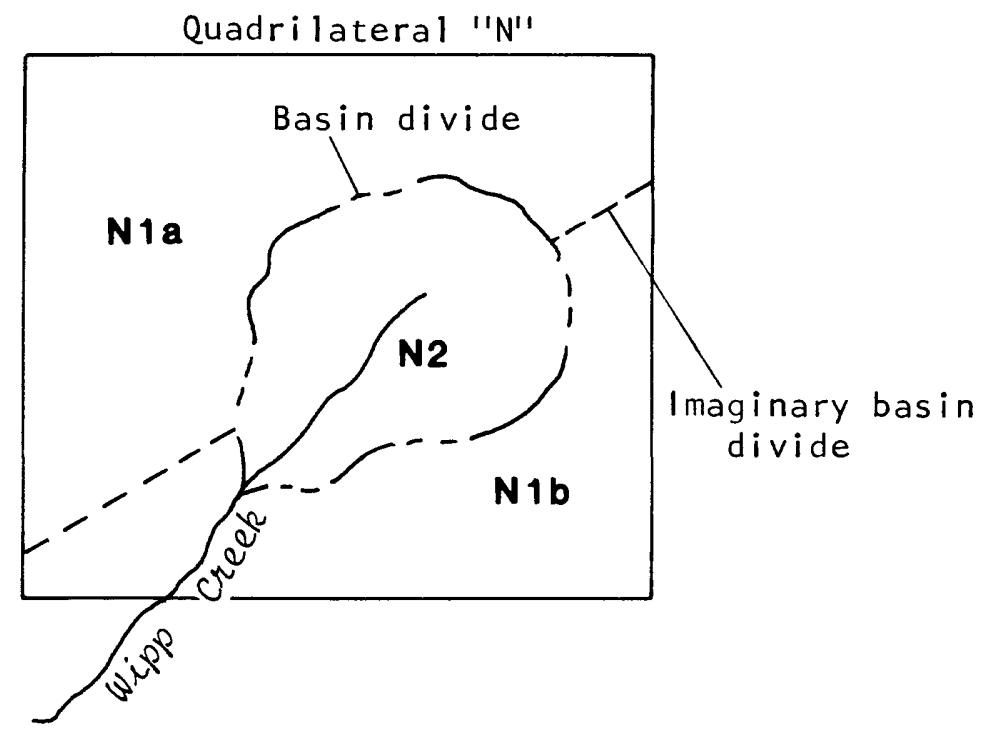

Figure 6.--Example of a drainage basin wholly contained in one quadrilateral. 


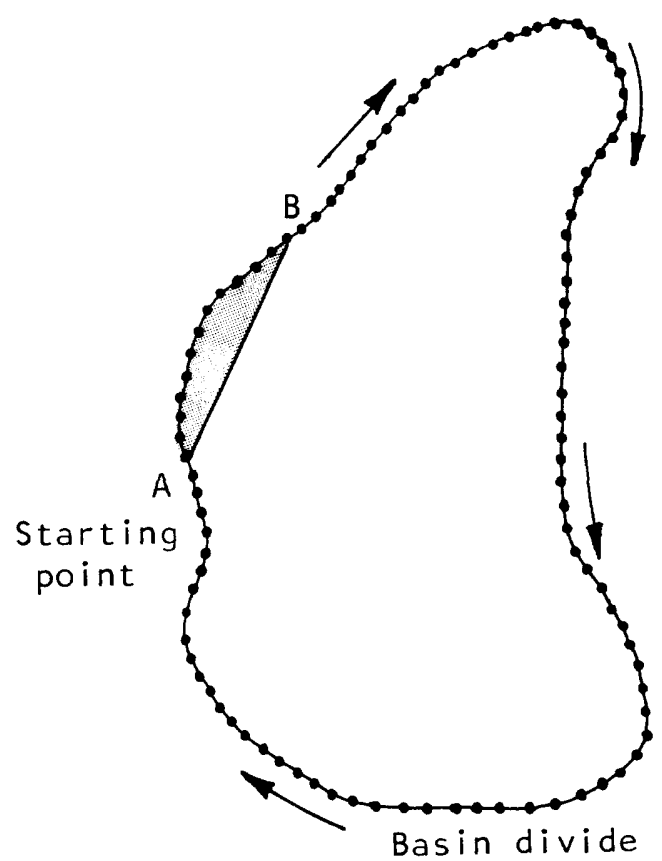

The curve represents a basin divide. If points $A$ and $B$ are entered consecutively, the shaded area will not be included in the total area. A data point needs to be entered for each point shown along the curve.

Figure 7.--Basin divide showing digitized data points.

The program then asks:

Do you wish to delete any runs $(\mathrm{Y} / \mathrm{N})$ ?

If no runs need to be deleted, use the printer/terminal to key in $\mathrm{N}$ and RETURN and continue these instructions from the point where the program asks, "Do you want to make any more runs (Y/N) ?"

If there are runs that need to be deleted from future calculations, key $Y$ and RETURN on the printer/terminal keyboard.

The program will then ask:

\section{Which run ?}

Key in the sequence number of the run to be deleted from the printer/terminal keyboard and then RETURN. The program will then respond by printing, "Run has been deleted."

The program again asks:

Which run?

Key in any single run number that should be deleted. If no further runs are to be deleted, key in RETURN on the printer/terminal keyboard. 
At this point the program asks:

Do you want to make any more runs $(\mathrm{Y} / \mathrm{N})$ ?

If no more runs need to be made, key in $\mathrm{N}$ and RETURN, and the program will continue to the next step. If further runs are needed, key in $Y$ and RETURN and make the runs using the above procedures.

After the final run has been made, the program asks:

What is the sub-basin I.D. ?

At this time enter the letter/number combination for the next subbasin. From figure 2, the I.D. would be $\mathrm{N} 2 \mathrm{~b}$. The program then allows the operator to digitize the subbasin using the above instructions.

After the last subbasin of the original basin has been digitized and the program has asked, "What is the sub-basin I.D. ? " key in RETURN.

The program will then ask:

What is the basin I.D. ?

If no further basins are to be subdivided on the same quadrangle, key in

RETURN . The program will terminate.

If there are other basins to be subdivided on the quadrangle, key in the new basin I.D. and basin area and digitize the subbasin using the above instructions.

If the program has been terminated for a quadrangle, the operator needs only to begin with the keying in of DAREA and RETURN in order to run other quadrangles in the same digitizing session.

The results of the drainage-area calculations will be stored in the selected computer file. A listing from such a file is shown in figure 8 . The printout includes the total computed area, the previously computed area, and the adjustment factor. The previously computed total area divided by the sum of the subbasin areas equals the adjustment factor. The new total area and the previously computed total area need to agree within 1 percent. The printout includes a listing of the subbasin I.D., the computed drainage area, the adjusted drainage area, and the sum of the adjusted areas. The sum of the adjusted areas needs to be equal to the previously computed total for the basin.

Once the drainage areas have been computed, computation and tabulation forms need to be completed. These are discussed in the following section. 


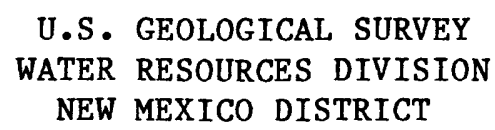

DRAINAGE AREA COMPUTATIONS

QUAD I.D.--- Wildhorse Mesa 7.5'

QUADRILATERAL AREA (SQ. MI.)--- 60.1200

CONVERSION CONSTANT $=0.143405$

BASIN I.D.-- N2A

$\begin{array}{cccc} & & \text { MAP } & \text { BASIN } \\ \text { SUB-BASIN } & \text { RUN } & \text { DRAINAGE } & \text { DRAINAGE } \\ \text { I.D. } & \text { NO. } & \text { AREA } & \text { AREA } \\ & & (\text { SQ. IN. }) & (\text { SQ. MI.) }\end{array}$

$\mathrm{N} 2 \mathrm{Al}$

$\begin{array}{llll}1 & 8.3888 & & 1.2030 \\ 2 & 8.3749 & & 1.2010 \\ 3 & 8.4028 & & 1.2050 \\ & & \text { AVERAGE }= & 1.2030\end{array}$

$\mathrm{N} 2 \mathrm{~A} 1$

N2A2

$\begin{array}{llll}\text { N2A2 } & 1 & 3.4308 & 0.4921 \\ & 3 & 3.4727 & 0.4980 \\ \text { N2A2 } & 4 & 3.4308 & 0.4920 \\ \text { N2A3 } & & \text { AVERAGE }= & 0.4930 \\ & 2 & 1.5481 & 0.2220 \\ \text { N2A3 } & 3 & 1.5481 & 0.2220 \\ & 4 & 1.5271 & \\ \end{array}$

TOTAL(SQ. MI.) FOR N2A

PREVIOUSLY COMPUTED TOTAL(SQ . MI.)

ADJUSTMENT FACTOR IS 1.0052
1.9170

1.9200

$\begin{array}{lcc} & \begin{array}{c}\text { COMPUTED } \\ \text { DRAINAGE } \\ \text { AREA } \\ \text { SUB-BASIN I.D. }\end{array} & \begin{array}{c}\text { ADJUSTED } \\ \text { DRAINAGE } \\ \text { AREA } \\ \text { (SQ. MI.) }\end{array} \\ \text { N2A1 } & 1.2030 & 1.2044 \\ \text { N2A2 } & 0.4930 & 0.4956 \\ \text { N2A3 } & 0.2210 & 0.2200 \\ & & 1.9200\end{array}$

Figure 8.--Example of a listing of computer file containing drainagearea program results. 


\section{COMPUTATION, TABULATION, AND COMPUTER- PRINTOUT RECORD}

Drainage-area computation, tabulation, and computer-printout records are important for future work. These records need to be filed in binders such as: (1) The computation records by river basin and alphabetically by quadrangle; (2) tabulation records by river basin, major tributary, and downstream order; and (3) the computer printouts by quadrangle, quadrilateral, and order of subdivision. Neat and concise records need to be completed for each drainage area determined.

\section{Drainage-Area Computation Sheets}

Since the use of the computer/digitizer system began, a new computation sheet has been designed (fig. 9). The sheet allows for entry of data from printed output of the computer program (fig. 8). The information that needs to be supplied for the table heading is: name of the map, bounding latitudes and longitudes, scale, contour interval, date of map, and horizontal datum. This information is available from the quadrangle map (fig. 1 ) and needs to be completed on the first page for each quadrangle.

The remainder of the computation sheet is filled out as shown in figure 9. In the column headed DIVISION SECTION, enter the quadrangle name in which the subbasins are located (1) (see (1) in fig. 9). An " $x$ " is placed in the quadrilateral diagram labeled $N$ in the upper right corner of the sheet to indicate that entries are for the north quadrilateral. Under the column heading QUAD AREA, enter the area for the quadrangle (2) from the report published by the Federai Inter-Agency River Basin Committee, Subcommittee on Hydrology (1951). The CONVERSION CONSTANT (3) is obtained from the computerprogram output.

Skip a line from the quadrangle I.D. and enter the subbasin I.D. of the first run (4). In the column headed AREA-SQUARE MILES, COMPUTED, enter the drainage area of each run used from the printout sheet (5) (fig. 8). Under the MEAN AREA column, enter the mean drainage area for the runs (6) from the printout. Also enter the ADJUSTED area rounded to the nearest hundredth (7). Repeat these entries for each of the subbasins.

When all subbasins are entered, skip a line and enter summation of the basin (8). Enter the sum of the mean areas (9) and the sum of the adjusted areas (10) in the columns titled MEAN and ADJUSTED, respectively. On the same line in the DESCRIPTION AND REMARKS column, note the page number of the computation sheet on which the previously computed area was found (11) and record the following values: Total $\mathrm{N} 2 \mathrm{a}=1.92$. On the next line, show how the adjustment factor was derived (12). 
WATER RESOURCES DIVISION

dRainage area COMPUtation-map Wildhorse Mesa 7\%' Latitude $35^{\circ} 15^{\prime} 00^{\prime \prime}$ to $35^{\circ} 22^{\prime} 30^{\prime \prime}$ scale 1:24000 Longi tude $105^{\circ} 45^{\circ} 00^{\prime \prime}$ to $105^{\circ} 52^{\prime} 30^{\prime \prime}$ Contour interval 20 feet. Date of map 1966 Horizontal datum MSh

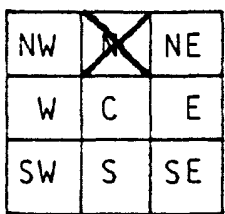

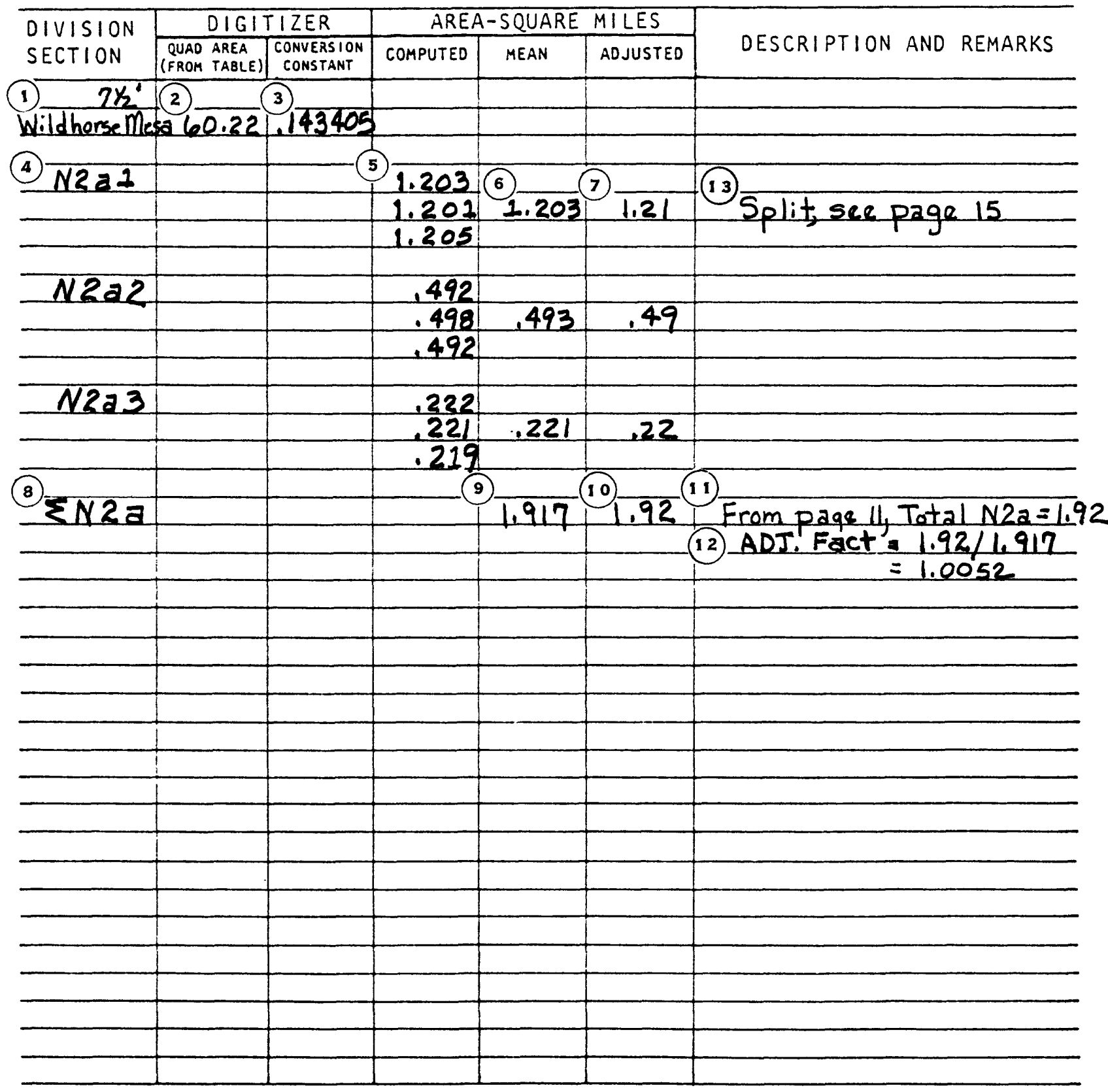

Figure 9.--Example of a computation sheet. 


\section{Computer Printouts}

The computer printout (fig. 8) needs to be filed in the folder labeled "Drainage-area printouts." The printouts need to be cut and trimmed to fit into the folder. The folder is subsequently filed in alphabetical order using the quadrangle name as the reference. The quadrilateral letters, arranged in alphabetical order, are used for the second order of filing. The final filing procedure uses the numbers and letters that indicate the order of division, as discussed in the section "Procedures for the determination of drainage area." When a subdivision (for example, N2al) is split into further subdivisions, this needs to be noted in the remarks column; for example, "Sp1it, see page 15" (13) . Page 15 will be a new page inserted in the correct order in the folder. The new page needs to refer back to the previous determination. (For $\mathrm{N} 2 \mathrm{a}$, see (11).)

\section{Tabulations}

After the computation sheet has been completed, the original basin tabulation filed in downstream order needs to be retrieved from the binder labeled "Drainage-area tabulations." Some large tributaries to the major streams may be tabulated separately. These tributaries need to be 1 isted in the front of the binder of the main stream to which they are tributary. The old tabulation sheet that does not include the new site needs to be crossed out and referenced to the new page being entered. The following instructions refer to the streams shown in figure 2 .

Fill in the heading of the drainage-area tabulation sheet (fig. 10), giving the major stream basin, the State, and the end points along the major stream to which the tabulation applies. On the first line under the column headed ABOVE POINT, record the drainage area of the site on the major stream immediately upstream from the first site being tabulated. The column headed ABOVE POINT is reserved for drainage areas determined at points on the major stream.

If a tabulation is to be made for a site on a tributary to the major stream, enter the drainage area determined for the first point directly upstream from the site in the column TRIBUTARY. In figure 10, no drainage area has been determined upstream along the tributary (Dukes Creek) so the value is zero and is not entered. Enter the name of the new site for the first tabulation. Record the QUADRANGLE name (1) (see number 1 in fig. 10). Under SECTION DIVISION, enter the subbasin I.D. (2). Commonly, as in the Wildhorse Mesa quadrangle example, more than one subbasin contributes to the total basin area for a site. Enter the ADJUSTED drainage areas of the contributing subbasins from the computation form in the ADJUSTED column (3).

For each site on a tributary to the major stream, such as Dukes Creek above tributary $\|_{1}$, add the adjusted areas $(0.04,0.03,0.25$, and 0.22$)$ to the previous drainage area under TRIBUTARY (in the example, zero, not entered) and enter the sum (0.54) under the TRIBUTARY column (4). This is the drainage area of Dukes Creek excluding tributary $\# 1$. 
GEOLOGICAL SURVEY

Drainage Area Tabulation for Beal Creak

State New Mexico

From Dukes Branch Headwaterst Beal Cresk at Hermitage

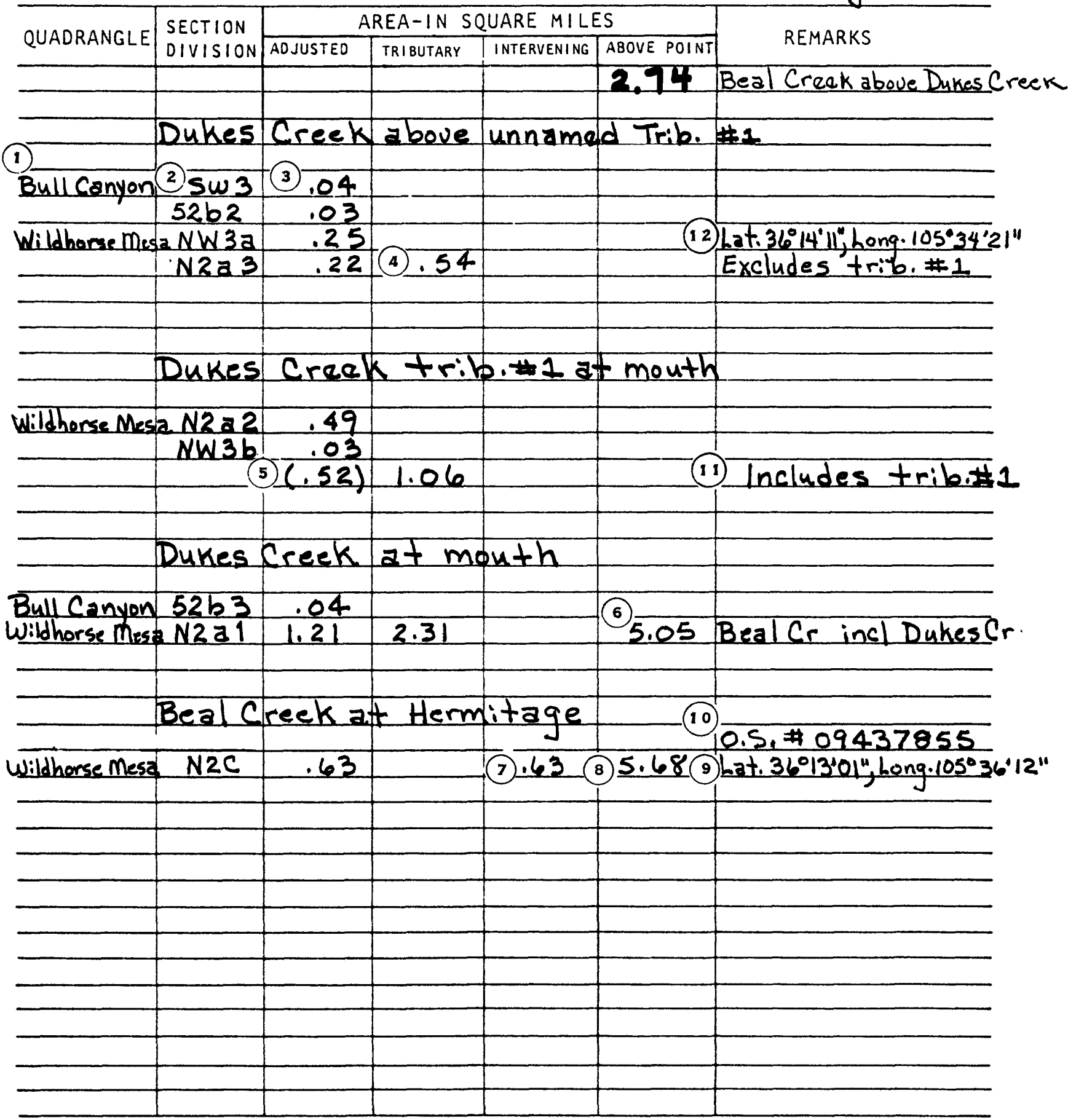

Figure 10.--Example of a tabulation sheet. 
Tabulation of the drainage area for Dukes Creek tributary 1 l is done next using much the same procedure as that used for Dukes Creek. A difference is that this stream is a tributary that does not enter directly into the major stream (Beal Creek).

If a drainage area has been determined for a point upstream, write the word "above" under QUANDRANGLE, and enter the appropriate drainage area in the ADJUSTED area column. In this example, the site is the first one for which a drainage area has been determined, and the "above" drainage area is not entered.

Follow the same procedure as used with the Dukes Creek tabulation in entering QUADRANGLE name, SECTION DIVISION identification, and ADJUSTED areas. Sum the areas $(0.49$ and 0.03$)$, and enter this value $(0.52)$ (5) in the ADJUSTED column in parentheses. This procedure is used in tabulating sites down Dukes Creek tributary \#l until tabulation, in parentheses, is made at the mouth.

To determine the drainage area of Dukes Creek including tributary $k_{1}$, add the drainage area in parentheses determined at the mouth of tributary \#1 $(0.52)$ to the drainage area of Dukes Creek above tributary $\equiv_{1}(0.54)$, and enter the sum 1.06 in the TRIBUTARY column.

Next, enter the name of the next site along Dukes Creek to be tabulated. If not done before, also enter the drainage area upstream from that point (1.06) and proceed in the same manner previously described for Dukes Creek.

The procedures described are used for the summation of drainage area for Dukes Creek to its mouth. Once the drainage area at the mouth is determined and entered under TRIBUTARY, add that area (2.31) to the last value entered in the ABOVE POINT column for Beal Creek above Dukes Creek (2.74), and enter the sum under ABOVE POINT (6).

If the site to be tabulated is on the major stream, as in the example "Beal Creek at Hermitage," sum the adjusted areas for basins draining directly in the major stream below the previously tabulated site, and enter the sum under INTERVENING (7). Add to the previous ABOVE POINT (6), and enter the sum under ABOVE POINT (5.68) (8) - This is the drainage area of the site.

In the REMARKS column, record the latitude and longitude of the site (9) and the downstream order number, if one has been assigned (10), and indicate whether the drainage area includes or excludes a tributary (11) and (12). 
Federal Inter-Agency River Basin Committee, Subcommittee on Hydrology, 1951, Inter-agency coordination of drainage area data: Washington, D.C., Bulletin no. 4,48 p.

Marra, S.R., 1982, FORTRAN 77 reference guide, revision 19.1: Framingham, Mass., Prime Computer, Inc., Doc4029-191, p. 150.

Talos Systems, Inc., 1979, SMART 2.0 manual: Anaheim, Calif., Manual no. 50111-1, revision $B, p .21$. 
SUPPLEMENTAL INFORMATION 
OK, darea

DAREA -- written by Kim Dalton and Dan Winkless, May 1983

What file do you want the information to be placed in?

river

What is the quadrangle I.D.?

Wildhorse Mesa $71 / 2$ '

What is the published quadrangle size(sq. mi.)?

60.12

digitize corners of quadrangle

4.18701E 02

What is the basin I.D.?

N2A

What is the basin area?

1.9200

What is the sub-basin I.D.?

N2Al

If you wish to see the areas, or delete any areas, digitize 0 .

digitize area

$0.83888 \mathrm{E} 01$

digitize area

$0.83749 \mathrm{E} 01$

digitize area

$0.84028 \mathrm{E} 01$

digitize area

$0,6.00585 \mathrm{E}-00,2.13525 \mathrm{E}-00$

$1 \quad 8.38880 \quad 1.2030$

$28.37490 \quad 1.2010$

$38 \quad 8.40280 \quad 1.2050$

Do you wish to delete any $\operatorname{runs}(\mathrm{Y} / \mathrm{N})$ ?

n

Do you want to make any more $\operatorname{runs}(\mathrm{Y} / \mathrm{N})$ ?

n

What is the sub-basin I.D.?

N2A2

If you wish to see the areas, or delete any areas, digitize 0 .

digitize area

$0.34308 \mathrm{E} 01$

digitize area

$0.55308 \mathrm{E} 01$

digitize area

$0.34727 \mathrm{E} 01$

digitize area

$0.34308 \mathrm{E} 01$

digitize area

$0,3.81738 \mathrm{E}-00,2.58056 \mathrm{E}-01$

$\begin{array}{lll}1 & 3.43080 & 0.4921\end{array}$ 


$\begin{array}{lll}2 & 5.53080 & 0.7931 \\ 3 & 3.47270 & 0.4980 \\ 4 & 3.43080 & 0.4920\end{array}$

Do you wish to delete any runs $(\mathrm{Y} / \mathrm{N})$ ?

y

Which run?

2

Run 2 has been deleted.

Which run?

Do you want to make any more $\operatorname{runs}(\mathrm{Y} / \mathrm{N})$ ?

n

What is the sub-basin I.D.?

N2A3

If you wish to see the areas, or delete any areas, digitize 0 .

digitize area

$$
\begin{gathered}
0.154810 \\
\text { digitize area } \\
0.154810 \mathrm{E} 01 \\
\text { digitize area } \\
0.15481 \mathrm{E} 01 \\
\text { digitize area }
\end{gathered}
$$$$
0,1.00476 \mathrm{E} 01,1.67382 \mathrm{E}-00
$$

$\begin{array}{rrr}1 & 0.1548 & 0.0222 \\ 2 & 1.54810 & 0.2220 \\ 3 & 1.54810 & 0.2210\end{array}$

Do you wish to delete any runs $(\mathrm{Y} / \mathrm{N})$ ?

y

Which run?

1

Run 1 has been deleted.

Which run?

Do you want to make any more $\operatorname{runs}(\mathrm{Y} / \mathrm{N})$ ?

y

digitize area

$0.15271 \mathrm{E} 01$

digitize area

$0,2.90332 \mathrm{E}-00,3.82324 \mathrm{E}-00$

$\begin{array}{lll}2 & 1.54810 & 0.2220 \\ 3 & 1.54810 & 0.2220 \\ 4 & 1.52710 & 0.2210\end{array}$

Do you wish to delete any runs $(\mathrm{Y} / \mathrm{N})$ ?

n

Do you want to make any more $\operatorname{runs}(\mathrm{Y} / \mathrm{N})$ ?

n

What is the sub-basin I.D.?

What is the basin I.D.?

$* * * *$ STOP 
OK, slist river

$$
\begin{aligned}
& \text { U.S. GEOLOGICAL SURVEY } \\
& \text { WATER RESOURCES DIVISION } \\
& \text { NEW MEXICO DISTRICT } \\
& \text { DRAINAGE AREA COMPUTATIONS }
\end{aligned}
$$

QUADRANGLE I.D.-- Wildhorse Mesa 7 1/2'

QUADRANGLE AREA (SQ. MI.)-- 60.1200

CONVERSION CONSTANT $=0.143405$

BASIN I.D.- N NA

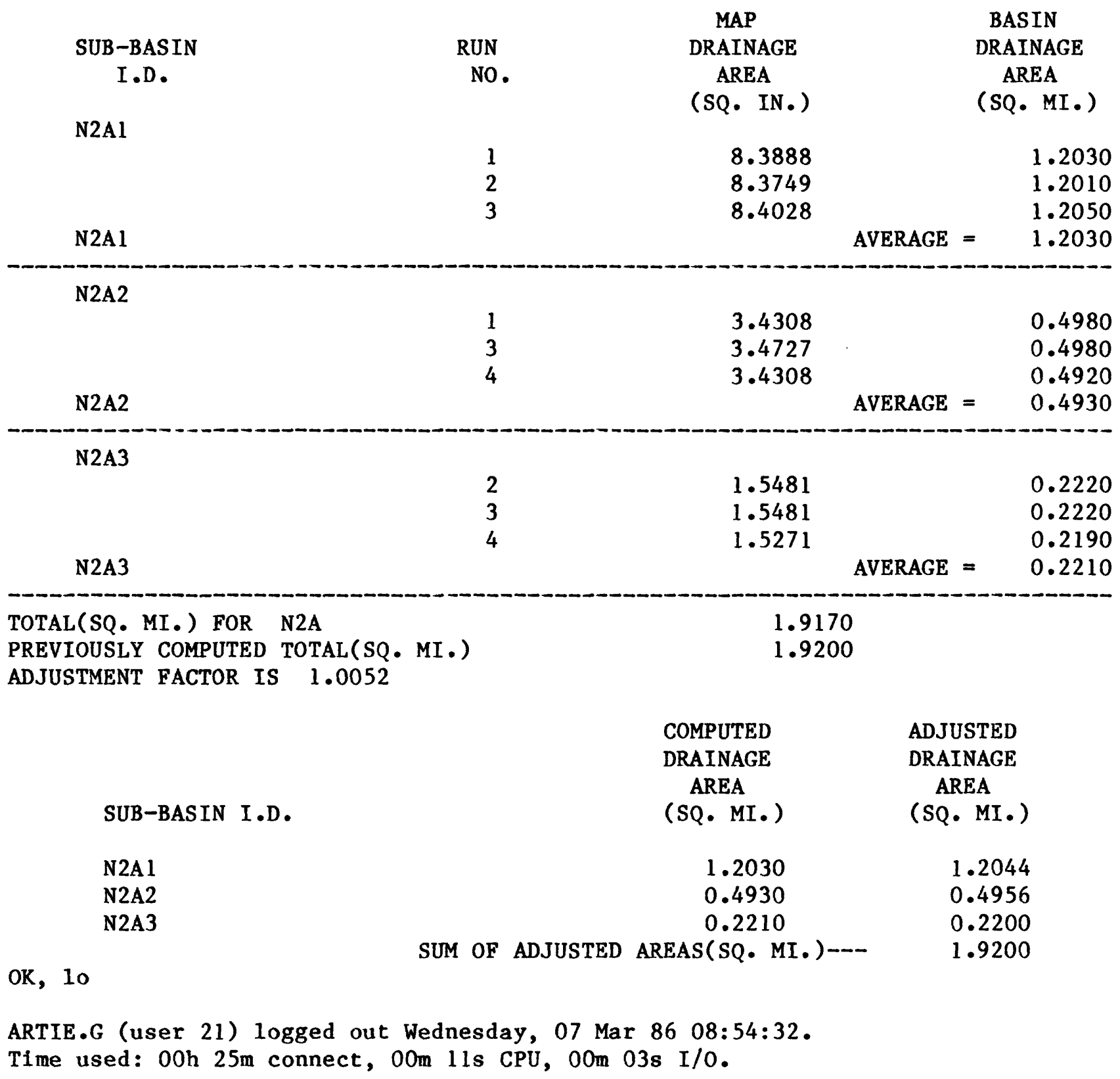


program DAREA

c This program helps the user determine drainage areas.

c

The program interracts with a user at the Talos digitizer. It prompts for all data needed.

c common/title/quadid, quadsize character $* 32$ quadid common/basin/factor, basid, basarea, adj character* 32 basid common/subdata/subtotal, subcnt, subid(30), ave(30), use(100), A $\operatorname{run}(100)$, end

logical use

character*32 subid

integer subcnt, end

write $(1, \mathrm{fmt}=$

1 '('DAREA -- written by Kim Dalton and Dan Winkless'',

2 ''May 1983''/)')

c

c

c

Get the name of the output file. (where the report goes.)

call startup

c

c

c

Get the published info about the quad.

write( 1 , fmt='('What is the quadrangle L.D.?'')')

read $(1,9)$ quadid

9 format (A32)

1 write $(1, \mathrm{fmt}=$

1 '('What is the published quadrangle size(sq. mi.)?'')')

read $(1, *$, err $=1)$ quadsize

c

c Now get what the digitizer thinks the quad area is.

c This lets us generate a conversion factor: sq.in.::map mi.

c

2 write ( 1, fmt='('digitize corners of quadrangle'')')

read $(1, *$, err $=2)$ quadarea

factor $=$ quadsize/quadarea

c

c

c

30 write( 1, fmt $=$ '('What is the basin I.D.?'')')

read $(1,9)$ basid

IF(basid.eq.' ')goto 100

c

c

c

c

For each basin we need a new report, so print titles. call titles

Find out how big the basin is that we are dividing.

Stay in a loop as long as the user has basins on this quad. 


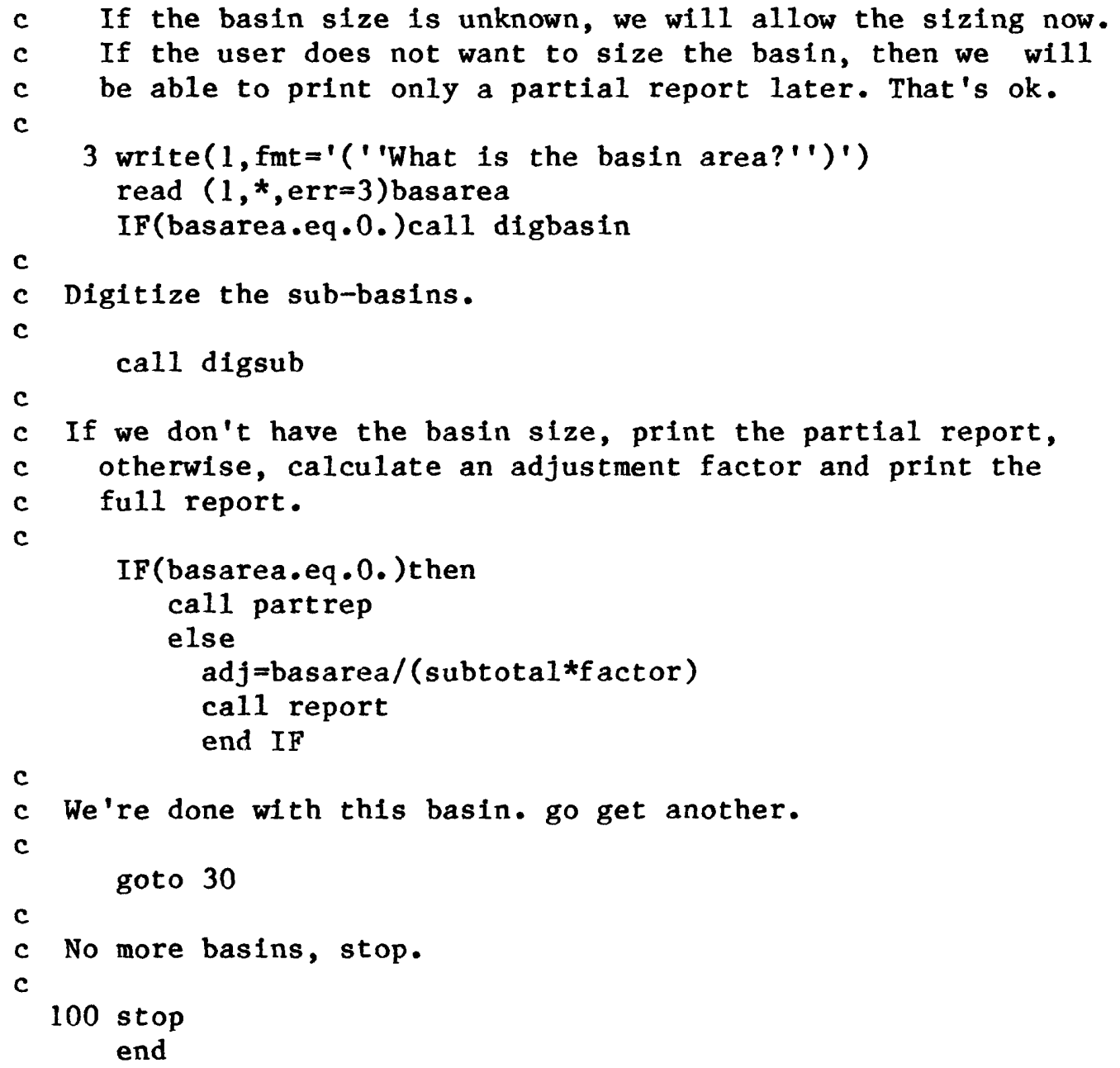




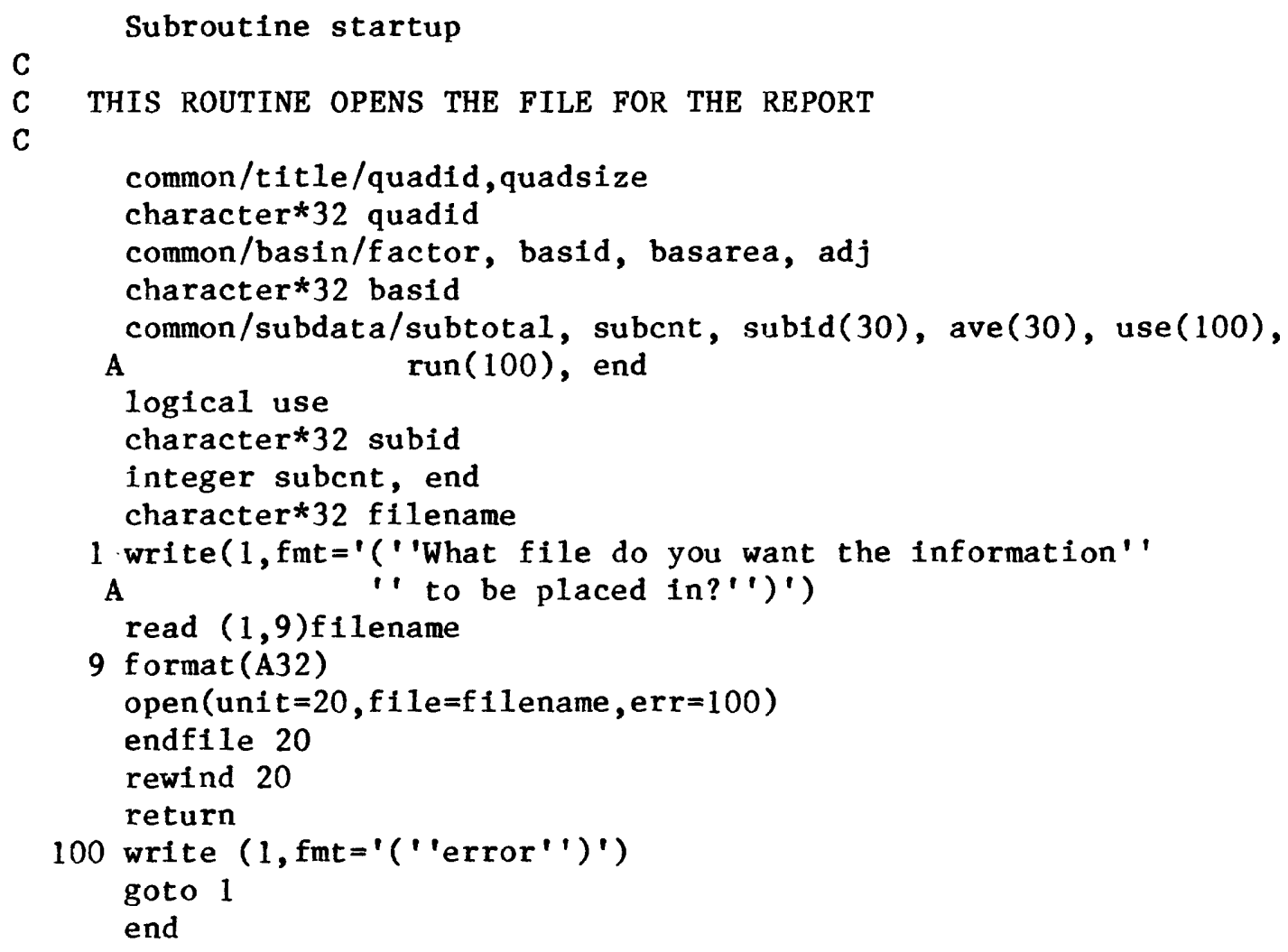




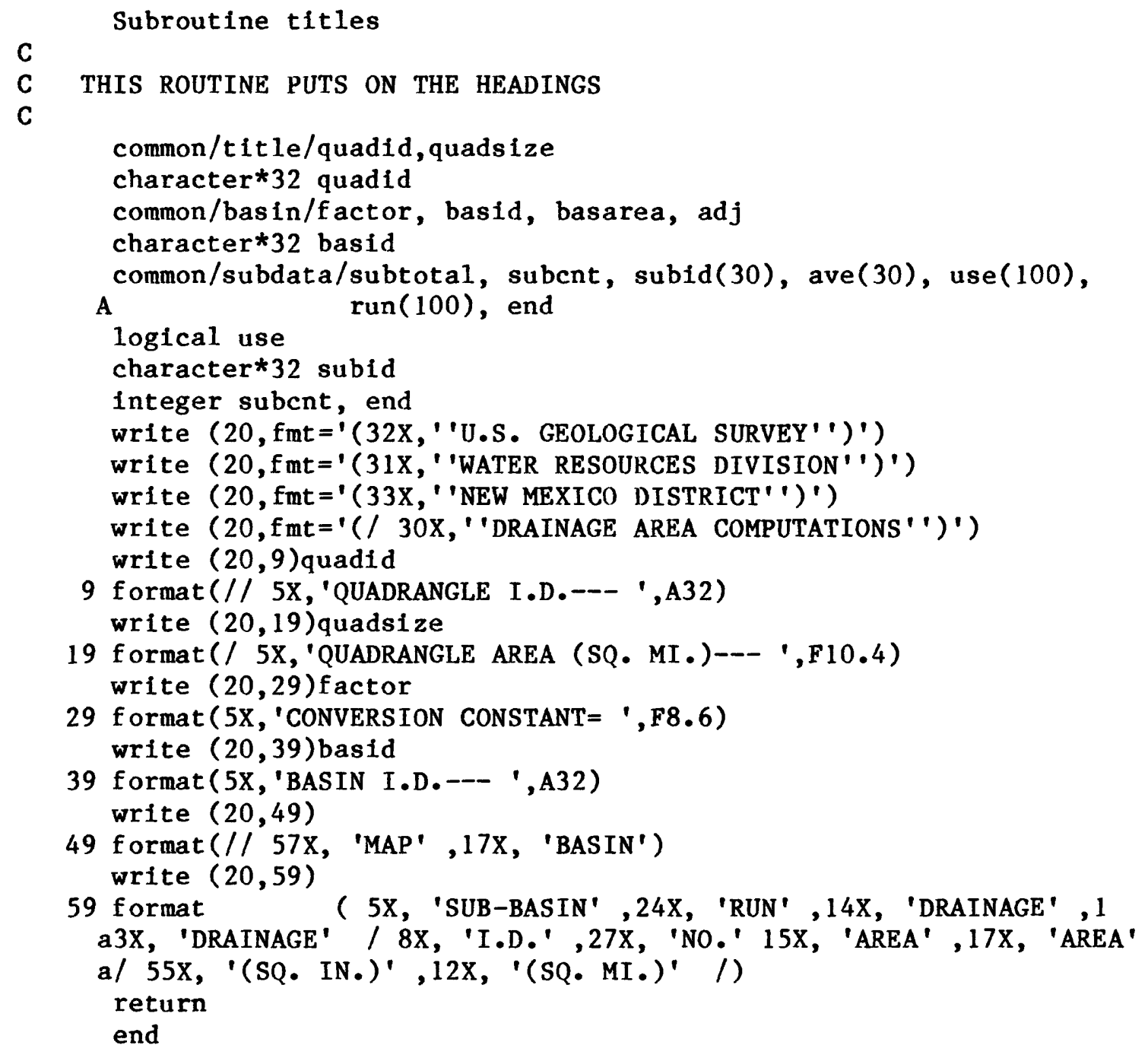


Subroutine digbasin

C

C THIS ROUTINE ALLOWS THE USER TO DIGITIZE THE AREA OF

C A BASIN IF THE AREA IS NOT ALREADY KNOWN.

C

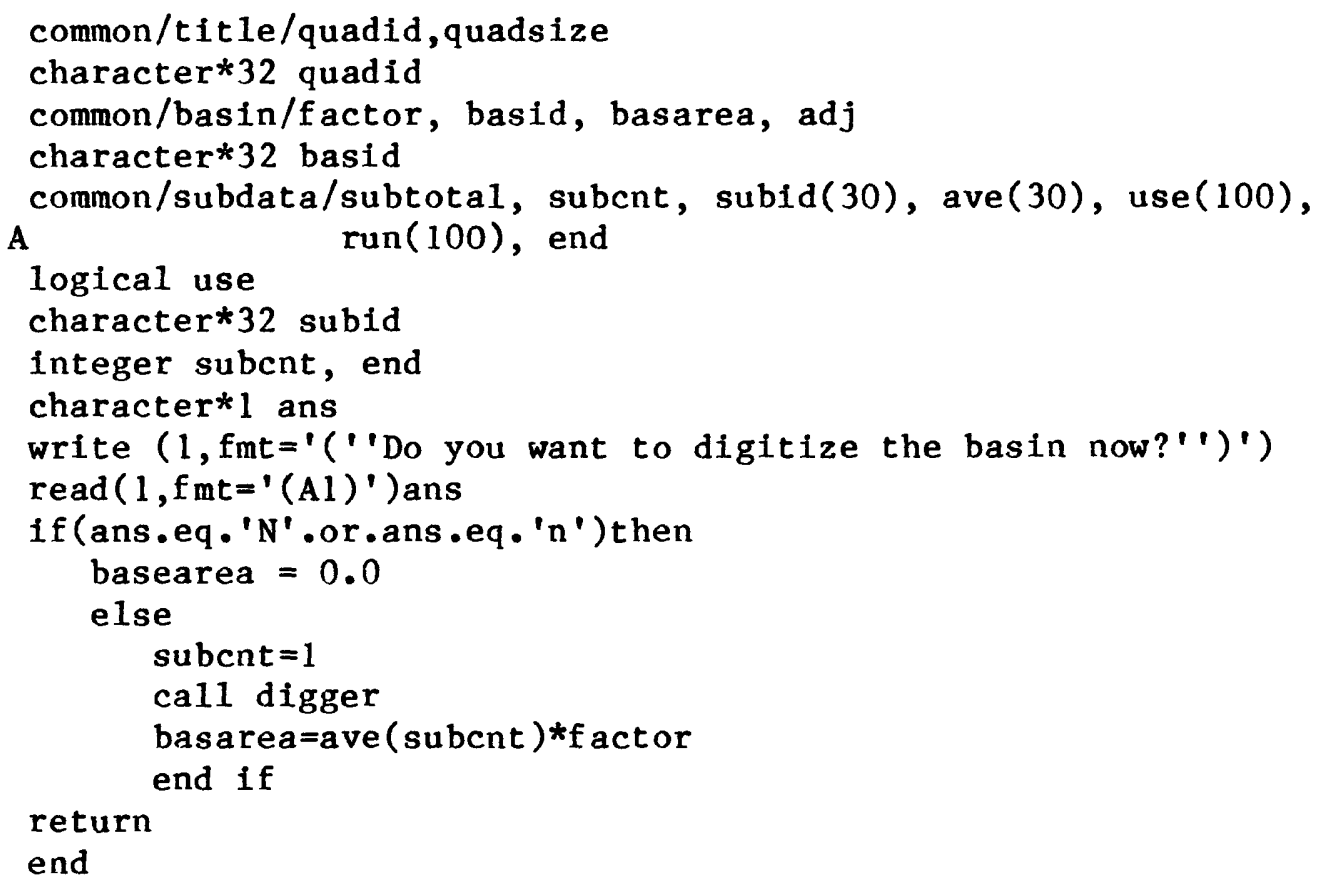




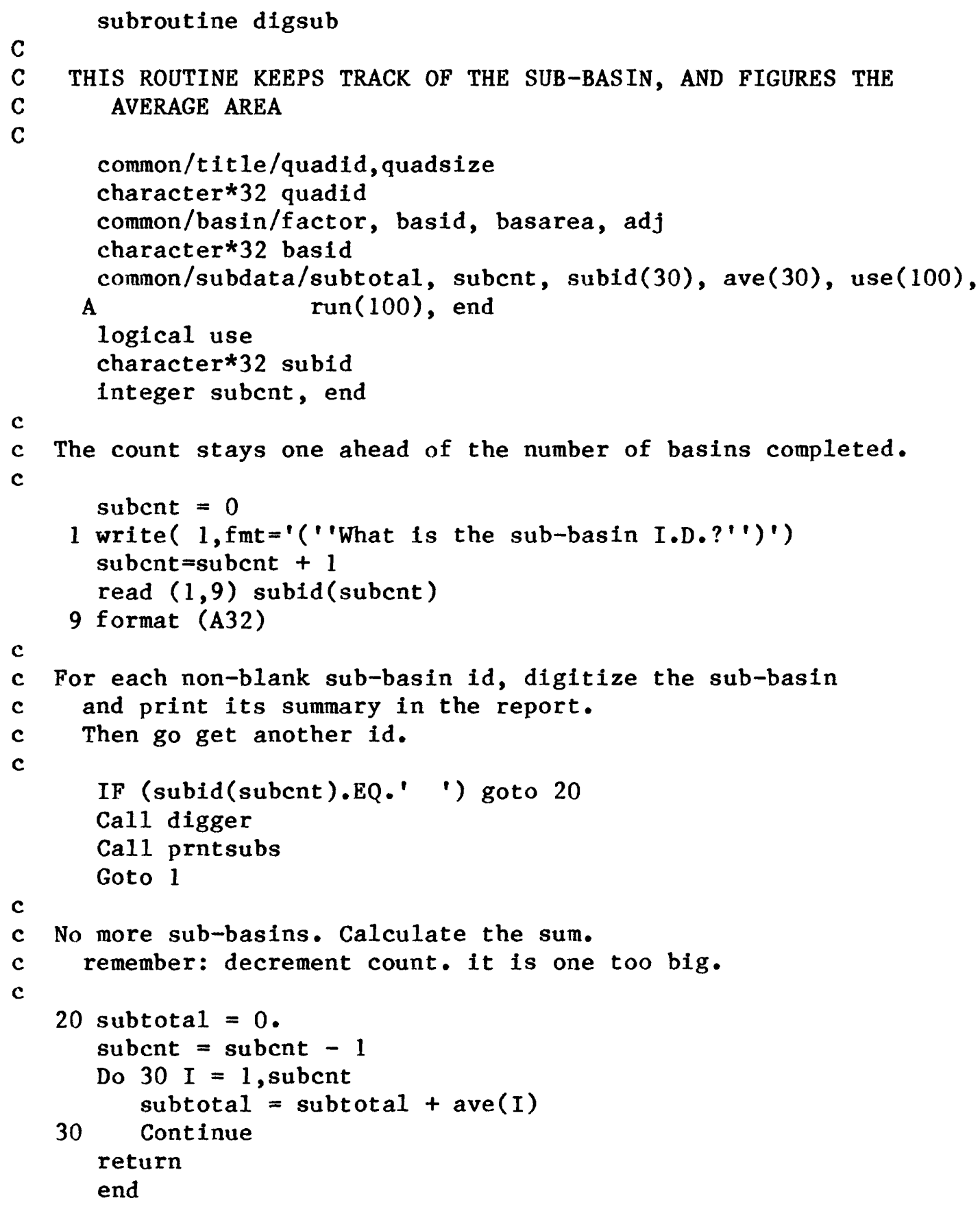


C THIS ROUTINE KEEPS TRACK OF THE DIGITIZED AREAS, ALLOWS THE USER TO

C DELETE AND ADD RUNS, AND FIGURES THE AVERAGE AREA OF THE "GOOD" RUNS

C

common/title/quadid, quadsize

character*32 quadid

common/basin/factor, basid, basarea, adj

character* 32 basid

common/subdata/subtotal, subent, subid(30), ave(30), use(100),

A $\operatorname{run}(100)$, end

logical use

character*32 subid

integer subent, end

integer count, point

character*1 in

c

count - counts the number of "good" runs. it is decremented

when runs are deleted, and it is incremented when

new runs are entered.

point - points to the next place to store an area. it is

incremented for each new run.

run - stores the area calculated by the digitizer for each run

use - is .true. for each "good" run

is .false. for each deleted run

a run is "good" until it has been deleted.

c

$$
\text { count }=0
$$

point $=1$

write ( $1, \mathrm{fmt}=$ '( /'If you wish to see the areas, or delete'" A ' any areas, digitize $0.1 ' /$ )')

c

c

c

1 IF(point .eq. 101)then

A write( $1, f m t=$ ' ('You have exceeded the number of runs '"

A ' 'allowed for one area. The program will continue'"/

''with the areas already entered.'')') end IF

2 write $(1, \mathrm{fmt}=$ '('digitize area'')')

read $(1, *$, err $=2)$ run(point)

IF ( run(point) .EQ.0.) goto 20

use $($ point $)=$.true.

point $=$ point +1

count $=$ count +1

Goto 1

c

c User entered a 0 for an area. Show him what he's done.

c Ask him for changes. 
c

20 end $=$ point -1

Do $30 \mathrm{I}=1$, end

IF(use (I)) then

29

write $(1,29) I, \operatorname{abs}(\operatorname{run}(I)), \operatorname{abs}(\operatorname{run}(I))$ * factor

end IF

30 Continue

c

c See if he wants to get rid of any areas.

c

40 write $(1, \mathrm{fmt}=$ '('Do you wish to delete any runs(Y/N)?'')')

read $(1,49)$ in

49 format (Al)

IF ( in.EQ.'N'.or.in.eq.'n') goto 60

c

c He does want to delete. Delete runs until he enters a 0 .

c

50 write $(1, \mathrm{fmt}=$ '('Which run?'')')

read $(1,59$, err $=50)$ num

59 format ( I3)

IF ( num.LE.0) goto 60

IF (num.LT.point.and.use (num)) then

$\operatorname{run}($ num $)=0.0$

count $=$ count -1

use (num) $=$. false.

write $(1,19)$ num

19 format ('Run ',I3, ' has been deleted.')

else

write (1,fmt='('Bad run number. Try again.'")')

Goto 50 end if

c

c

c

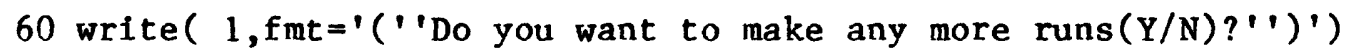

read $(1,49)$ in

IF ( in.EQ.'Y' .or. in .eq. 'y') goto 1

c

c All runs entered. calculate average of "good" runs.

c

total $=0$

65 Do $70 \mathrm{I}=1$, end

IF ( use(I) ) then

total $=\operatorname{total}+\operatorname{abs}(\operatorname{run}(I))$

end IF

70 Continue

IF (count .gt . 0)then

ave (subcnt) $=$ total/count

else

ave (subcnt) $=0.0$

end if

return

end 


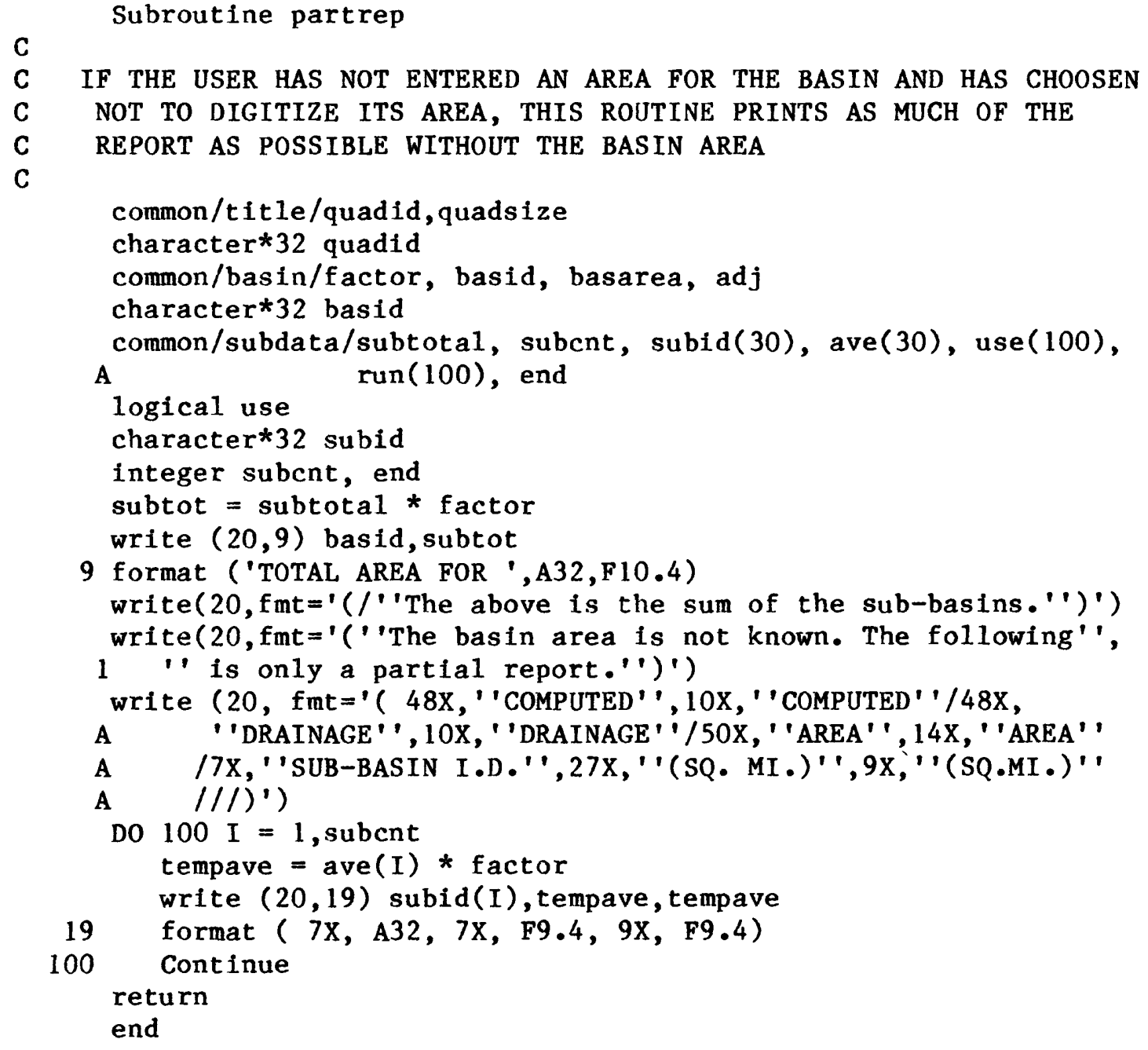


Subroutine prntsubs

C

C THIS ROUTINE PRINTS ALL THE GOOD RUNS FOR A SUB-BASIN

C (SQ. INCHES AND SQ. MILES)

C AND FOLLOWS IT WITH THE AVERAGE IN SQ. MILES

C

common/title/quadid, quadsize

character $* 32$ quadid

common/basin/factor, basid, basarea, adj

character $* 32$ basid

common/subdata/subtotal, subcnt, subid(30), ave(30), use (100), A $\operatorname{run}(100)$, end

logical use

character*32 subid

integer subcnt, end

write $(20,9)$ subid (subent)

9 format ( $5 X, A 32)$

Do $100 \mathrm{I}=1$, end

IF ( use(I)) then runn $=\operatorname{run}(I) *$ factor write $(20,19) I, \operatorname{run}(I)$, runn

19 format ( $39 \mathrm{X}, \mathrm{I} 2,14 \mathrm{X}, \mathrm{F9} .4,13 \mathrm{X}, \mathrm{F9} .4$ ) END IF

100 Continue

facave $=$ ave (subcnt) * factor

write $(20,29)$ subid(subcnt), facave

29 format ( $5 \mathrm{X}, \mathrm{A32}, 30 \mathrm{X}$, 'AVERAGE $=$ ', F9.4)

write $(20, \mathrm{fmt}=$ '( $86(' \cdot-') /)$ ')

Return

end 


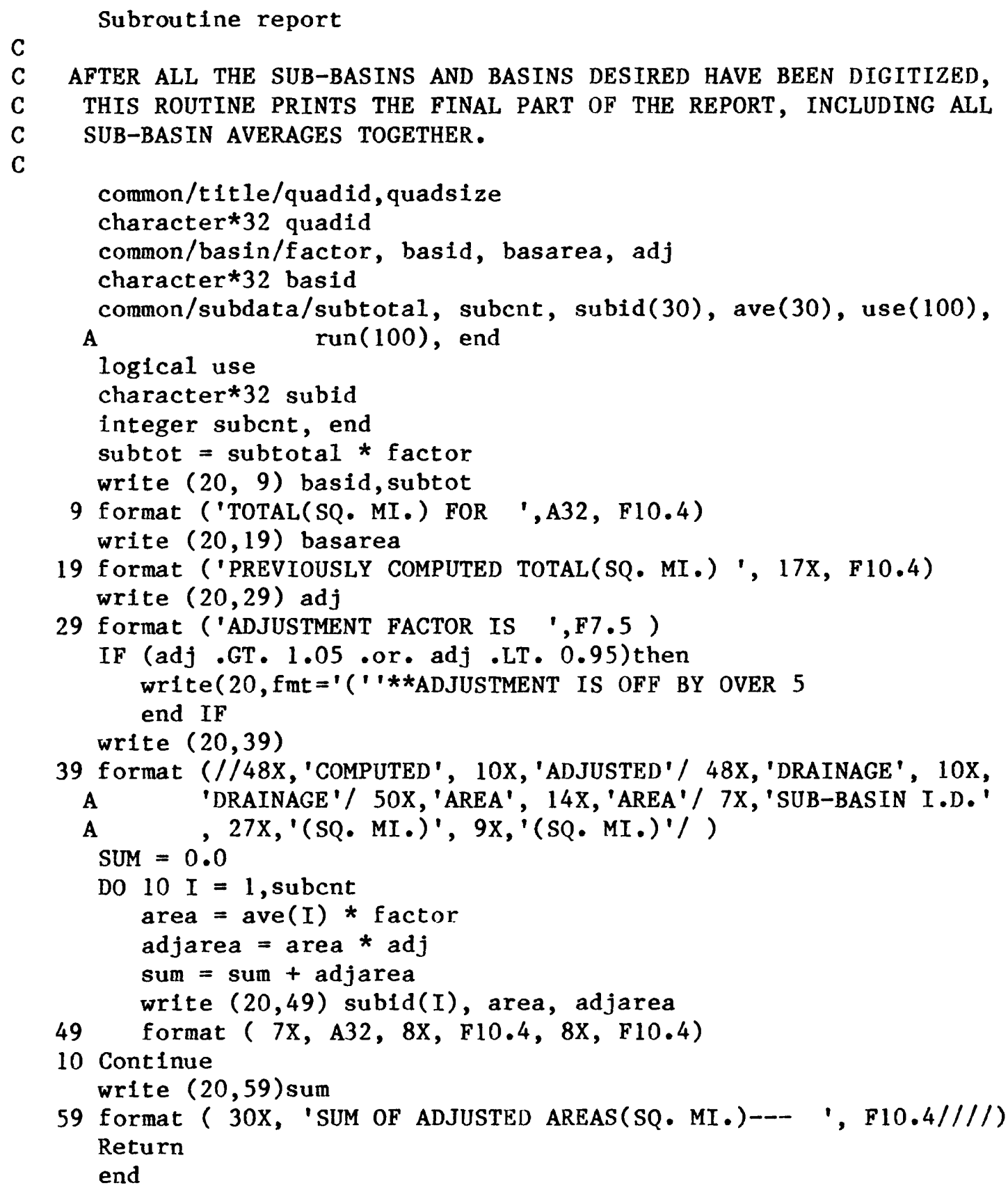

